\section{Soviets honour teamwork and technology}

It is sixty years after the revolutionbut the 1977 Soviet State Prizes for Science and Technology show no sign of anniversary euphoria. The works cited seem genuinely to reflect the current state of progress, without any attempt to honour 'great names' on this special occasion. There is considerable emphasis on teamwork: the majority of citations involve long lists of project-directors, assistants, and technicians, so that the announcement of 38 awards with the names, academic or professional titles, and affiliations of the recipients fills a page of Pravda.

The citations span the usual wide range from mathematics to biology, with occasional incursions into fields not normally considered sciences in the West-Marxism and its ancillaries of history and economics. Current Soviet doctrine, as expounded at recent Party Congresses, demands that science should serve the national economy. Accordingly, several prizes go to research directly related to official priorities - a set of geological maps of Western Siberia, special equipment for land reclamation, fisheries equipment, and the use of discrete transformations in automatic control. The recent voyage of the icebreaker Arktika to the North Pole won a State Prize for her designers and engineers (though not for the scientific team aboard).

The medical sciences, which have recently received a new priority including the establishment of the title of merit "People's Doctor of the USSR", are well represented. Three science prizes go to long-term medical research: two-for haematology and prophylactic helminthology-mention "cycles of works" published over the last 15 years, while the third-one of the very few individual awards-cites a haematological monograph which also implies a long-term basis of research. Medicine also receives two technology prizes, where the citations seem rather more adventurous-new equipment for hyperbaric oxidation, and the "clinical development and implementation" of methods of limb transplantation.

In a year of setbacks for the space programme, it is not surprising to find space ignored in the technology section, although it does receive one science award-for research into the $\mathrm{X}$-ray emission of the sun.

Nuclear research receives only one

Chris Sherwell, News Editor of Nature for the past two years, has taken up a post on the foreign desk at the Financial Times. Robert Walgate, until recently with New Scientist, takes $\mathrm{Mr}$ Sherwell's place. And David Dickson, recently with the Times Higher Educational Supplement, becomes our Washington News Editor at the beginning of 1978 . nuclear physics. economic geography. definite yet. award-for research into the hard $\mathrm{X}$-ray fission of light nuclei. Commenting on this prize, the Chairman of the State Prize Committee, Minister of Higher and Secondary Specialised Education, Vyacheslav P. Elyutin, stated that "this work is of exceptional significance for the study of thermonuclear reactions and radioactive fallout". Nevertheless, in view of the repeated acclaim given in the Soviet media this last year to the fast-breeder power programme, it is a little surprising that there is no technology prize for nuclear enginering. The only other mention of nuclear physics is in the "textbook" section-for a twovolume university text on experimental

This separate section for textbooks is a relatively recent innovation. In the Soviet Union, textbooks are selected by the educational authorities on a Union-wide basis, so that, on occasion, criticism of an unsatisfactory text will lead to a discussion in top-level party journals. The demand for scientific personnel is expanding with each Five Year Plan-the current Plan requires an "output" from the universities and institutes of higher education of 9.6 million new scientists, technologists and specialists in the period 1976 to 1980 , so the provision of suitable textbooks is a matter of ever-increasing importance. This year two other university textbooks, on pedology and invertebrate palaeontology, are also honoured, as is a secondary school text on

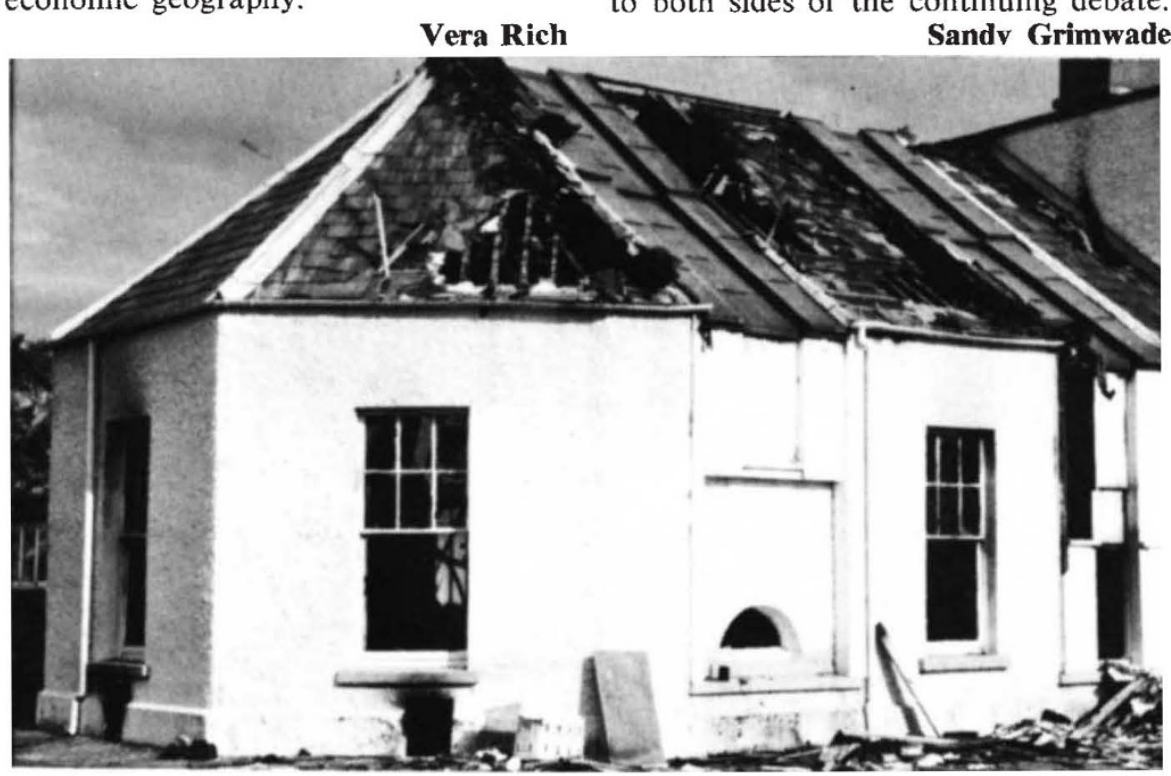

Above: the Meridian Room at the Dunsink Observatory of the Dublin Institute for Advanced Studies, where a major fire early last October severely damaged the library and laboratories. Loss of instruments has meant loss of valuable work. But Professor P. A. Wayman, Director of the Observatory, is hopeful that the observatory will be restored. He sees as first priority getting the smoke damaged computer back into action. Restoration of the eighteenth century building which housed the library is likely, though not

The Observatory was founded in 1783 and became part of Dublin University. In 1947 it was taken over by the Dublin Institute. It has no telescopes of its own. 